\title{
Chapter 7: Prospects for Agri-Food Trade Between Russia and China
}

\author{
Jiayi Zhou
}

\section{INTRODUCTION}

Amidst the backdrop of ever heightening tensions between the United States and China, a June 2019 meeting of the Russian and Chinese presidents witnessed their bilateral relationship upgraded to a 'comprehensive strategic partnership of coordination in a new era'. In the summit's joint statement, Russia and China agreed to expand bilateral agricultural cooperation, including for soybean trade. President Vladimir Putin later that year would remark that the U.S.-China dispute offered a window of opportunity for Russian producers to fill gaps in the Chinese market, a market from which he claimed the United States had 'voluntarily withdrawn'.

The China-U.S. trade war paused in the beginning of 2020 with the signing of the Phase One economic and trade agreement. However, questions remain as to how the shifting geopolitical landscape is impacting trade in general, and food trade in particular. Indeed, the politicisation if not weaponisation of food trade among the great powers is

\section{J. Zhou $(\bowtie)$}

Stockholm International Peace Research Institute (SIPRI), Stockholm, Sweden e-mail: zhou@sipri.org

(C) The Author(s) 2022

S. K. Wegren and F. Nilssen (eds.), Russia's Role in the Contemporary

International Agri-Food Trade System, Palgrave Advances

in Bioeconomy: Economics and Policies,

https://doi.org/10.1007/978-3-030-77451-6_8 
evidenced not only by the China-U.S. soybean battle, but also by Russia's ongoing countersanctions against Western food imports. Unsurprisingly, Russia-China agricultural cooperation is framed and interpreted within the broader context of both countries' tensions with the West. ${ }^{2}$

This chapter explores Russia-China agri-food trade as part of that context, as part of a relationship marked by increasingly close rapprochement if not entente. However, in agricultural trade as in the broader political relationship, high-level declarative cooperation is tempered by the countries' respective national and domestic priorities, which are not always aligned. China is and will remain an important trade partner for Russia to reach its main export goals for 2024. However, the chapter thus cautions there are a number of technical as well as political hurdles to enhance trade cooperation.

The chapter proceeds with an overview of Russia-China economic relations, before turning to agri-food trade relations in particular-which has only recently begun to feature as a priority in that relationship. The chapter then turns to their respective national priorities in the agricultural trade sector. On the Russian side, priorities are marked by ambitious export-oriented targets as well as a broader economic turn to the (Far) East. On the Chinese side, authorities emphasise self-sufficiency and prioritise domestic production, particularly in terms of grain. However, China has also become irreversibly dependent on foreign markets, and is also interested in mitigating overseas supply chain risks through the diversification of its agricultural trade partners. The fourth section outlines the prospects and challenges of deepened trade cooperation in specific agricultural commodity and product groups, with an emphasis on Russian exporters' access to Chinese markets. The chapter finally turns to a number of broader structural barriers to deepened bilateral agri-food trade, before concluding with a medium-term outlook.

\section{Bilateral Relations}

In the more than three decades since the normalisation of diplomatic relations between the Soviet Union and the People's Republic of China, relations between the neighbouring powers have grown to become a constitutive feature of international relations. ${ }^{3}$ Long-standing territorial and border demarcation issues were worked out throughout the 1990s, and definitely resolved in 2005 . Already by 1996, the relationship had formally become a 'strategic partnership', entailing the establishment of 
annual meetings of prime ministers with policy consultation along with a number of issue domains. And in 2001, at the beginning of Putin's first term, a Russia-China 'Treaty of Good Neighbourliness, Friendship and Cooperation' was signed, which also included a number of strategic provisions, including strengthened bilateral military cooperation as well mutual defence consultation.

The two powers have, over the past three decades, aligned in their criticism against Western military interventionism, and become outspoken proponents of a 'multipolar' world order. They often hold joint positions on key global issues-including as permanent members of the UN Security Council. The two also have common if not shared foreign policy emphases on state sovereignty and similar threat perceptions, as well as domestic political governance models antithetical to the Western liberal democratic norms. There is a considerable amount of speculation and analysis as to whether a formal alliance is in the cards for the future: though officials' statements suggest that it is not (indeed, this would violate basic tenets of China's non-alignment foreign policy). ${ }^{4}$ But there also remains a degree of ambivalence regarding the nature of the relationship. Throughout the early 2000s, Russian foreign and economic policy was oriented towards the West rather than East. Russia policymakers exhibited concerns over sensitive technology transfers, Chinese migration in the Russian Far East, as well as Chinese encroachment in the broader post-Soviet space. Meanwhile, China's own priorities centred around maintaining a stable external environment for domestic economic growth; its foreign policy attention was therefore primarily oriented towards its main trade and investment partners in the United States and other developed countries. Many aspects of the relationship thus remained declarative: high-level, but with limited operational substance.

By the late 2000s, however, it was increasingly clear that Russia's experiment with the Western integration had reached a limit. A pivot to the East took shape, one that coincided with the emergence of China as economic powerhouse. Since the 2014 crisis in Ukraine, Russia's drive to improve ties with China has intensified. Previous ideas that the relationship with China constituted an 'axis of convenience' rather than a strategic priority for Moscow, have become less relevant. ${ }^{5}$ Indeed, previous stumbling blocks in the bilateral relationship have since been resolved. In addition to the 2014 signing of a long-term gas deal, Russia has also begun selling its most advanced weapons systems the $S-400$ anti-aircraft system and its Su-35 fighter jets to China. ${ }^{6}$ Russia invited China to 
participate in Vostok-2018, held in the Russian Far East and its largest military exercise since 1981, and the two have conducted joint air patrols since. ${ }^{7}$ In 2015, their respective flagship foreign economic initiatives, the Russia-led Eurasian Economic Union (EAEU) and China's Belt and Road Initiative (BRI) also signed a cooperation agreement.

On the Chinese side, economic and political tensions with the United States have visibly worsened since 2018 , which have likewise stimulated a desire for deepened cooperation with Russia. In declarative terms, the relationship between the two countries had by 2011 already been upgraded to a 'comprehensive strategic partnership of cooperation', a singular category in China's foreign relations that applies to Russia alone. ${ }^{8}$ President Xi Jinping, who came to power in 2012, has embarked on more state visits to Russia than any other country. ${ }^{9}$ On his state visit to Moscow in June 2019, Xi referred to Putin as 'my closest foreign colleague, and best friend', while Putin referred to the relationship as a 'truly comprehensive partnership and strategic interaction' and as having reached an 'unprecedentedly high level'. ${ }^{10}$

At the same time, however, the high-level pronouncements by Moscow and Beijing are belied by more anaemic cooperation on the ground. This is particularly the case in the economic realm where programmes and plans usually face disappointing follow-up and delivery in practice. ${ }^{11}$ Latent tensions remain, including Sinophobia and concerns over territorial sovereignty. ${ }^{12}$ Economic relations have long been asymmetric, with Russia frequently referred to as the 'junior partner' in the relationship: the Chinese economy has only grown and improved while Russia's is stagnant and remains largely based on extractive commodities. Indeed, while China has been the largest trade partner for Russia outside of the European Union (EU) since 2010, Russia ranked only 10th among China's trade partners in 2019, rising from just 0.8 percent in 2018 to just under 3 percent of China's overall trade turnover. ${ }^{13}$ Meanwhile, China accounted for about 15.8 percent of Russia's total trade turnover in 2018, at about $\$ 108.2$ billion USD. For comparison, U.S.-Chinese trade exceeded $\$ 659.8$ billion USD in 2018 , over six times the RussiaChina level. Russia, moreover, largely supplies the Chinese economy with raw materials, with Russia becoming China's largest supplier of crude oil in 2018.

Meanwhile, the extent and success of Putin's pivot eastwards have been debated, given unmet expectations that China would be able to fill the gap of Western investors and trade partners. ${ }^{14}$ Russian actors also tend 
to emphasise that their pivot eastwards is not limited to China, but is also oriented towards strengthening partnerships with Asian governments including South Korea and Japan. Concerns of overreliance and becoming outcompeted domestically, are present for both Russian policymakers and in EAEU-BRI negotiations regarding free trade. ${ }^{15}$ Nevertheless, enhancing trade is a policy goal on both sides. At the September 2019 Heads of Government meeting in St. Petersburg, the countries agreed to nearly double the current level of trade, to a targeted \$200 billion USD by 2024 .

\subsection{Bilateral Agricultural Trade Relations}

During the first half of the 1990s, up to 1997, Russia was a net importer of agricultural goods from China. The agricultural trade balance began to even out in the rest of the decade, but the overall volume remained low, peaking at just over $\$ 1$ billion USD in $1993 .{ }^{16}$ From the 2000s onwards, however, the volumes of agri-food trade have seen steady growth in both directions, increasing approximately 16 percent annually between 2000 and 2014-when the bilateral agricultural trade volume reached $\$ 3.85$ billion USD. Prior to the Ukraine crisis, Russia counted as China's 15th largest agricultural trade partner, amounting to approximately 2 percent of China's agricultural trade. ${ }^{17}$ In terms of agricultural commodities, Russian trade with China has been relatively balanced (see Fig. 1).

Agri-food exports from Russia to China show a steady increase since 2014 , and then a big jump in 2018 to just under $\$ 3$ billion USD, a result of Russian opportunism during the U.S.-China trade war (see Fig. 2). While China is the largest export market for Russian agri-food products, Russia accounted for only 2 percent of China's agricultural imports in 2018, reflecting the overall direction of economic dependency. ${ }^{18}$ Moreover, agriculture still represents a rather small proportion of Russian exports to China, amounting to only 4.5 percent of the total in $2018 .{ }^{19}$ In the first half of 2020 , Russian exports increased to $\$ 1.9$ billion USD worth of agricultural products, a pace that would lead to a record level if maintained for the duration of $2020 .{ }^{20}$ Going forward, there is ambition by both sides to raise the level of agricultural trade and cooperation as part of the broader economic, political, and strategic relationship under a so-called 'new era' of bilateral cooperation between China and Russia. Given the attention of the highest political leadership, this means that 


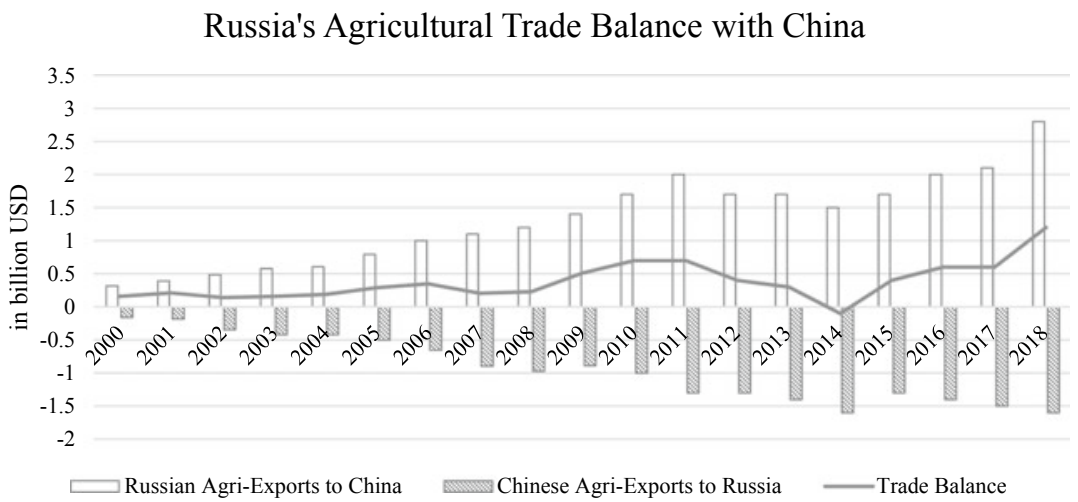

Fig. 1 Russia-China agricultural trade balance (Source Author's rendition from data in Chatham House, 'Exploring Interdependencies in Global Resource Trade', 2018. http://resourcetrade.earth/, accessed 29 October 2020)

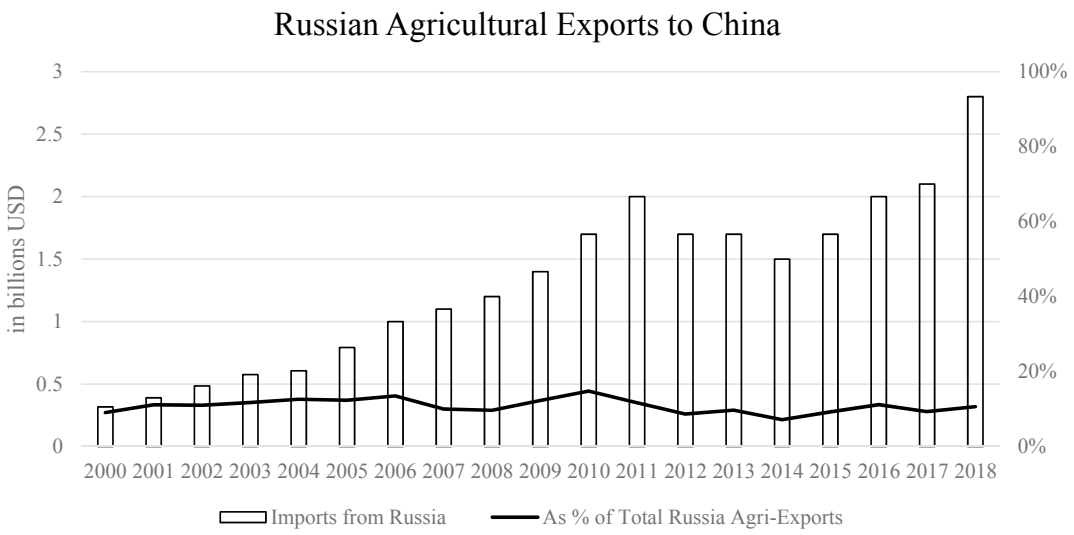

Fig. 2 Russian agricultural exports to China (Source Author's rendition from data in Chatham House, 'Exploring Interdependencies in Global Resource Trade', 2018. http://resourcetrade.earth/, accessed 29 October 2020)

there is likely to be increased policy support for enhanced cooperation in agricultural trade.

The main Russian agricultural export to China during the past two decades has consistently been fish and seafood. Exported largely as raw 
materials for Chinese processing, these products consisted of up to over 90 percent of Russian agricultural exports to China up until the early $2010 s^{21}$ Since then, there has since then been some diversification in the structure of Russian agri-food exports to China, particularly in the direction of oilseeds and fat products as well as some processed foodstuffs. In 2018, fish and crustaceans accounted for 59 percent of agri-food exports to China; oilseed and oilseed products 15 percent; and highervalue-added processed food products at 13 percent. ${ }^{22}$ Russian imports of Chinese agricultural goods, on the other hand, have strongly reflected Chinese comparative strengths in labour-intensive goods such as vegetables and fruits. In 2018, those two categories accounted for nearly half of Chinese exports to Russia.

\section{Respective National Priorities}

There are important domestic drivers for agricultural cooperation on both sides. At the same time, however, those self-same national domestic priorities also create certain limiting conditions for the future. For example, it is important to note that both Russian and Chinese agri-food policies are marked by strategic considerations, in particular, national self-sufficiency. Since at least the early 2010s, the Russian state has embarked on an ambitious import substitution campaign, of which agriculture features prominently. ${ }^{23}$ Contours of this policy were outlined in the 2010 Food Security Doctrine, which set self-sufficiency targets in various agricultural product categories. These were made more stringent in a 2020 update. Russia's import ban against Western agricultural products in 2014 was also framed as contribution to those goals; the Russian Ministry of Agriculture has celebrated the reduction of agricultural imports by onethird since the ban was imposed. ${ }^{24}$ In short, Russian leadership, while reorienting its trade relations away from the West, has simultaneously endeavoured to limit imports more generally. At the same time, there are ambitious agri-export targets, as exemplified by Putin's statement in 2012 , that in the next four to five years we must fully ensure our independence in all major types of food production, and Russia must then become the world's largest producer of food'. ${ }^{25}$

China has likewise held a long-standing policy of self-sufficiency in staple grain products, including wheat, corn, and rice, since the mid1990 s. $^{26}$ These priorities limit the complementarily of the two markets, 
given that the current structure of Russian agricultural exports is concentrated in grain. However, Chinese remains a significant agricultural importer outside of the grain category, and demand is growing. China is actively seeking to diversify its suppliers for key agricultural commodities, as well as seeking further agricultural investment opportunities and markets abroad, not least due to the trade tensions with the West. The following subsection describes their respective policies and priorities in greater detail, focusing on Russia's export strategy as it relates to China as well as its vision for internal agricultural development, for which China is seen as a key partner. It also details Chinese policy priorities in this regard.

\subsection{Russian Export Targets and RFE Development Priorities}

Current Russian export goals are defined by the 2018 Executive Order 'On national goals and strategic objectives for the development of the Russian Federation for the period up to 2024'. This tasks the Russian government with increasing the volume of exports of non-primary nonenergy goods to $\$ 250$ billion USD by 2024 . Specific sub-targets include increasing exports of agricultural products to $\$ 45$ billion USD, more than double the export value in 2017. ${ }^{27}$ In late 2020, Russia's Ministry of Agriculture acknowledged that the $\$ 45$ billion USD goal was unlikely to be reached and the deadline needed to be extended, although the general trend in agri-food exports was upwards. As defined by the Ministry of Agriculture's plan 'Exports of AIC [agro-industrial complex] Products (2018-2024)', agri-exports of all categories should grow, but with a reduction in the proportion of grain exports towards meat and dairy, oilseed products, and processed goods. ${ }^{28}$ The plan also sets a target for agricultural exports to China to increase to $\$ 7.7$ billion USD by 2024 , and China also features as an explicit target market in individual product categories. $^{29}$

Related to these ambitious export targets, a priority for the Russian state is agricultural development in the Russian Far East (RFE), which borders China. While the underdevelopment of the RFE has been a historic issue for authorities in Moscow, it began to receive more sustained attention alongside the broader pivot eastwards. ${ }^{30}$ A specialised Ministry for the Development of the Far East was established in 2012, and Putin would highlight the development of Siberia and the Russian Far East as a 'national priority for the entire twenty-first century'. ${ }^{31}$ This has been 
recently reconfirmed at, among other venues, the 2018 Eastern Economic Forum (EEF) during which Putin reiterated that 'the development of the Far East is an absolute priority' and part of a 'consistent, long-term policy for the country'. He also singled out agriculture as a particular sector for investment as well as part of the region's comparative advantage. ${ }^{32}$ A follow-up draft 'National programme for the development of the Far East for the period up to 2025 and to 2035' was developed in $2019 .{ }^{33}$ The Russian government plans to increase agricultural exports from the RFE from $\$ 3.8$ billion USD to $\$ 5.9$ billion USD by $2024 .{ }^{34}$ Much of that increase is expected to come from fish, seafood, and soybean, whose production is concentrated in the RFE. However, whether those goals will be reached substantially depends on whether promised levels of federal funding and support will be dispersed. RFE development programmes have a habitual tendency to be underfunded; during a 2019 Presidium, it was noted by RFE regional officials that such programmes very often do not have sufficient implementation mechanisms, and that sources of funding have in the past been dispersed only at the level of 10-20 percent level of original promises. ${ }^{35}$

To facilitate development, foreign direct investment into the RFE has long been sought, particularly from Northeast Asian partners and not limited to China. ${ }^{36}$ However, Chinese investment in the region is most notable, and still is considered critical. In 2016, for example, a Russia-Chinese Agro-Industrial Development Fund of \$10 billion USD was announced, of which nearly 90 percent of the capital was to be provided by Chinese investors. ${ }^{37}$ At the $2018 \mathrm{EEF}$ - a forum set up to attract foreign investors-Putin estimated that the Chinese were involved in around 30 ongoing projects in the RFE, with an investment volume of approximately $\$ 200$ billion USD. ${ }^{38}$ However, it is important to note that data about foreign investments tend to be incomplete, with underreporting across both Russian and Chinese governmental departments and agencies. ${ }^{39}$

Agriculture has featured in bilateral regional development plans, including the Program of Cooperation between the Regions of the Far East and Eastern Siberia and the Northeast of the People's Republic of China (2009-2018), the first long-term regional cooperation plan to include agriculture. ${ }^{40}$ The Sino-Russian Cooperation and Development Plan in Russia's Far East Region (2018-2024) also contains provisions on agriculture. The document recognises that the lower food self-sufficiency 
of the RFE creates opportunities for increased Chinese investment, while also aimed at increasing RFE agricultural exports to China. ${ }^{41}$

In addition to providing investment, Chinese individuals and companies also farm a significant amount of RFE territory. ${ }^{42}$ Much of China's agricultural activity in Russia is concentrated along those border regions, and there are estimates that this constitutes anywhere from 350,000 hectares to 400,000 hectares of farmland. There is some uncertainty due to the informal nature of some leasing arrangements: the governor of the Jewish Autonomous Oblast, where Chinese presence is purported to be the largest, notes that official land titles do not reflect the reality of Chinese production, due to informal leasing practices. ${ }^{43}$

Thus, Russia's desire for development in the RFE for which both Chinese capital and labour are critical, juxtaposes with concerns about economic overreliance as well as the encroachment of Chinese nationals on domestic territory. Agriculture-specific concerns also include putative predative exploitation by Chinese farmers, and possible longer-term reduction of soil fertility due to intensive agricultural practices and use of chemical fertilisers. ${ }^{44}$ This leads to a fickle and uncertain policy environment for Chinese investors. ${ }^{45}$ For example, the aforementioned bilateral agreements to enhance imports from China contradict other domestic guidelines to make the region less reliant on imports from China. ${ }^{46}$

\section{Prospects for Increasing Russian Exports}

As noted in Fig. 2, since 2014 there has been significant growth in the volume of agricultural trade between Russia and China, and in particular in the volume of Russian agricultural exports to China. One important driver of the increase has been the devaluation of the ruble. ${ }^{47}$ But the increase also reflects that Russia has now gained access to the Chinese market in key product categories, with the clearing of important phytosanitary hurdles in the past five years when protocols for grain, soybeans, poultry, beef, and dairy, and other items have been signed. This certainly bodes well for the future of Russia-China agricultural trade. However, it is worth pointing out that the current increase is from a negligible baseline.

Separate from market access is a question of market competitiveness, for which according to Karlova and Serova Russia's advantages are 'fairly limited'. ${ }^{48}$ As officials in Russia's Ministry of Agriculture acknowledge, 'China is the country to which all export-oriented countries want to 
supply their products. We are no exception'. ${ }^{49}$ Rising living standards and changing dietary patterns in China will continue provide to Russia opportunities to increase food exports. But Russia faces competition against already-dominant exporters of soybeans, oilseeds, meat, and dairy, as well as from emerging markets with whom China has been concurrently cultivating closer agricultural trade ties in recent years. The westernisation of Chinese consumption entails greater demand for higher-value productswith a commensurate focus on quality - which are not historically Russian strengths although that situation is changing.

In addition, the Chinese economy is not only marked by significant demand. China also dominates in the global production of many agricultural commodities. Besides being the world's largest single producer of grain, it is also one of the world's largest exporters of fruits and vegetables, and fish and seafood. The latter it exports at twice the level of Russia, even while serving as Russia's largest buyer. Further, for a number of sensitive commodities, including by not limited to wheat, corn, rice, sugar, and wool, China applies strict tariff-rate quotas (TRQs). In the long run, this puts an upper limit on what Russian producers can hope to export. Given these considerations, the following analysis discusses Russian prospects for increasing the presence of the Chinese market in a few important product categories. I then return to broader structure barriers to enhancing agri-food trade.

- Grain: The Chinese market was closed to Russian wheat export since 1997 due to discovery of karnal and dwarf bunt pathogens. However, phytosanitary barriers were resolved in 2015 after the two sides signed a protocol for wheat, corn, rice, soybeans, and rapeseed. ${ }^{50}$ As of 2020 , wheat exports are allowed from seven Russian regions, including Chelyabinsk, Novosibirsk, Omsk, Amur, Krasnoyarsk, Altai, and Kurgan. ${ }^{51}$ Current volumes of export are limited. In 2018, Chinese imports amounted to a mere 86.7 thousand tonnes. Corn imports were equally limited at 40 thousand tonnes. ${ }^{52}$ However, in general more and more grain categories are open for Russian exporters. In 2018, a protocol on allowing Russian exports also of buckwheat, oats and oatmeal, millet, as well as other products including semolina and rye flour to China. ${ }^{53}$ 
China regulates grain trade through TRQs. Within quota tariffs for edible grains are set at a low 1 percent but outside the quota tariffs are a prohibitive 65 percent, and with limited licences that usually go to the major Chinese state-owned enterprises. ${ }^{54}$ What imports do arrive are usually of very high quality and for a niche market. There is little indication that Chinese authorities will loosen their food security principles. At the same time, basic staple commodities such as corn, rice, wheat, are also becoming less important for the Chinese diet. Thus, according to Arkady Zlochevsky, the president of the Russian Grain Union, 'there are no particular prospects for the growth of grain sales'. ${ }^{5}$

- Fish and seafood: One of the areas where Russia has a strong foothold in the Chinese market is fish and seafood and these have comprised the bulk of Russian agricultural exports to China for a long time. In 2018, China accounted for 47 percent of Russia's fish and seafood exports, with an export value of $\$ 1.2$ billion USD. China serves as Russia's main fish and seafood market, meanwhile Russia serves as China's largest foreign source of frozen fish. Russian fish exports to China are dominated by frozen pollock, approximately half the supply, as well as crabs. However, currently these Russian exports are for the most part unprocessed and low value added.

- Meat: China is one of the world's largest meat producers as well as importers. ${ }^{56}$ Pork is the main source of animal protein in the Chinese diet, for which China has historically been more or less self-sufficient. But starting from 2018, the African Swine Flu (ASF) and decimation of China's pig stocks have led it to turn more to international markets, as well as to alternative meats. China has only recently opened as a destination for Russian meat exports, but as of the first half of 2020 it has already become the main destination. ${ }^{57}$ At a September 2019 Russian Ministry of Agriculture meeting dedicated to the export of meat products, China was identified as one of the most promising markets, with an emphasis on poultry. ${ }^{58}$ Poultry indeed exports currently comprise the bulk of meat exports to China.

After being banned in 2005 due to outbreaks of avian influenza, the two countries signed a protocol for mutual trade of frozen poultry in November 2018. In February 2019, the first shipment of 54 tonnes 
came from the Russian company Miratorg. ${ }^{59}$ The company Cherkizovo, Russia's largest poultry producer, also began exporting chicken in May $2019 .{ }^{60}$ By the end of 2019, Russia had exported approximately 62 thousand tonnes, worth \$143.4 million USD, to China. Currently, chicken wings as well as chicken feet are primary parts being sold, in light of competition against dominant poultry exporters for parts for which Russia is not competitive. A number of requirements unique to the Chinese market, including on the processing side, however, remain to be met across the poultry industry. ${ }^{61}$ Despite being the second largest producer in the world, China's poultry consumption and its imports are also expected to continue to grow. ${ }^{62}$

In January 2020, Cherkizovo also began to export turkey meat to China with an initial volume of 27 tonnes. In terms of beef, China has become one of the world's fastest growing markets: from a low starting point of 20,000 tonnes of beef imports in 2011, China imported nearly 1.7 million tonnes in 2019 and is now the world's second largest importer behind the United States. ${ }^{63}$ In 2020, the companies Miratorg and Zarechnoe were provided licences to export beef to China, and a first shipment of 21.4 tonnes arrived in Shanghai in May. ${ }^{64}$ Chinese imports of Russian beef will certainly grow from such a small baseline. However, Russian beef production is currently not produced at a competitive price, and in scale it is unlikely to challenge Brazil, Argentina, Uruguay, and Australia for any significant share of the Chinese market.

Growth in Chinese demand for poultry and beef is partly due to a substitution effect. ASF had decimated China's pig stocks by at least half (one-quarter of the world's production) by the end of $2019 .{ }^{65}$ China's pork imports rose that year to 2.11 million metric tonnes and were expected to peak in 2020 before domestic production can recover. ${ }^{66}$ Whether and how much the crisis-induced diversification towards other meat products will continue long-term remains to be seen. However, it is notable that even in 2018, analysts were predicting that China had reached 'peak pork', due both to a switch to alternatives in beef and poultry, but also due to government emphasis and consumer interest in reducing meat intake in general. ${ }^{67}$

As of mid-2020, Russia does not export any pork to China; pork exports to China were banned in 2008 due to ASF concerns. Russia's comparative advantages against larger exporters like the EU, Brazil, and Canada that are interested to taking advantage of the increased demand are also not obvious. ${ }^{68}$ Nevertheless, projections by the Chinese Ministry 
of Agriculture are that meat imports will continue to increase during the next decade. ${ }^{69}$ To the extent that Russian meat production keeps pace, the Chinese market will continue to represent an opportunity for growth.

- Dairy: Since 2010, China has also been the world's largest importer of dairy products, amounting to over one-fifth of the global market. ${ }^{70}$ At the end of 2018, an agreement on the import of 22 categories of Russian dairy products was also reached. Until then, ice cream was the only dairy product entering into the Chinese market. However, due to logistical factors including cold storage, high transport costs, quality control issues, as well as consumer preferences, traditional dairy products such as milk or yogurts from Russia are less competitive. ${ }^{71}$ However, more processed dairy products may have room for growth-though falsification and quality control here remains an issue. ${ }^{72}$

- Soybean and oilseeds: A category of significant attention by policymakers on both sides is soybeans, largely imported for animal feed in China. Since China abolished its import quota system for soybeans as part of its WTO accession commitments, it has become the world's leading importer and accounts for two-thirds of the international market. Due to insufficient if not diminishing arable land, water, and other resource constraints, dependence on foreign soybeans is viewed as largely irreversible. In mid-2018, China placed an effective ban on soybean imports from one of its largest suppliers. Since then, Chinese authorities and state-owned enterprises have been explicit about the need to diversify China's soybeans import structure, to involve more South American states, Canada, as well as the Black Sea region encompassing Russia and Ukraine, as well as Kazakhstan also. ${ }^{73}$ As the president of state-owned China Oil and Foodstuffs Corporation (COFCO), China's largest grain trader and food processing company Yu Xubo stated, longer-term supply diversification of soybeans will present a 'historic opportunity for other countries'. ${ }^{74}$

Five Russian provinces were allowed to export soybeans to China in 2015 , after phytosanitary approval by Chinese authorities. That year was the first in which any meaningful volumes were exported by Russia to China; by 2018 the volume reached 817 thousand tonnes. During Xi's 
visit to Moscow in June 2019 the two sides signed a 'Plan for Deepening Cooperation between Russia and China in Soybeans' according to which the goal is for China to import 3.7 million metric tonnes of Russian soybean by $2024 .^{75}$ This has since been connected to the larger project of reaching $\$ 200$ billion USD in total bilateral trade by $2024 .^{76}$ In July 2019, the Chinese General Administration of Customs approved imports of soybeans from all territories of Russia, as well as expanding modes of transport to include sea shipping. ${ }^{77}$

China is the primary buyer of Russia's soybean crop. The volume, however, is notably small when compared to China's overall imports of 88 million metric tonnes. Russian targets are expected to more than double the value of soybean exports from 2018 , to $\$ 600$ million USD by $2024 .^{78}$ Estimates regarding the potential of soybean export vary, however. Some experts are sceptical that 3.7 million metric tonnes to China can even be reached considering climate, geographic factors, and the scarcity of available arable land. ${ }^{79}$ According to Dmitry Ryl'ko, head of the Institute for Agricultural Market Studies, the RFE's potential for soybean is already 'practically exhausted' and a maximum of 2 million metric tonnes is more likely. ${ }^{80}$ Finally, Russian soybeans are non-GMO. There are also advantages to this (see below), but among other issues, including pests and lower yields, Russian soybeans are not competitively priced against other major exporters. ${ }^{81}$ Thus, while there are prospects for growth, it is likely that Russian soybeans will remain a negligible part of China's overall demand. ${ }^{82}$

As for other oilseeds and oilseed products, sunflower oil has notably been competitive in the Chinese market. Sunflower oil is a relatively niche product, viewed as a healthier alternative to standard cooking oils. Different packaging standards and expectations-for example litre sizehowever, can limit its appeal. ${ }^{83}$ Moreover, Russia faces high competition from Ukraine, including due to infrastructural issues and port capacity. ${ }^{84}$ Regarding other intermediary products, a 2019 protocol for Russian export of soybean, rapeseed, sunflower meal was also signed. ${ }^{85}$

- Ecological products: Genetically modified (GM) foods are seen in a negative light by a substantial proportion of Chinese consumers. Since GM production was banned in Russia in 2016, an opportunity exists for Russia to expand its non-GMO exports to China. ${ }^{86}$ For example, soybean imports are suitable for niche 'ecological' markets, in particular for non-animal feed uses of soybean. ${ }^{87}$ Other niche 
markets include processed products such as soy milk, soy sauce, tofu, and other seasonings. Non-GMO food presents an advantage for the marketing of healthy products for higher-end markets. Russian legislation including the 2020 federal law 'On Organic Products' on this should assist with labelling and quality standards in this regard. ${ }^{88}$ Notably, the development and marketing of ecological products is also a part of Russian export strategy.

- Higher value-added products: Russian leadership is quite clear about the need to move up the supply chain, towards processed and value-added products rather than raw agricultural materials and bulk commodities export. In this area, Russia's chocolate confectionary products have a strong showing on the Chinese market, comprising $\$ 112.6$ million USD of $\$ 438$ million USD total Chinese imports of chocolate products in 2019. ${ }^{89}$ Russian brands of beer and ice cream have also made inroads into the Chinese market. ${ }^{90}$

Overall, to reach its export targets for 2024, Russia's exports will need to move beyond bulk commodities and raw agricultural materials exports. This requires not only domestic processing, but also vertical integration both at industrial and regulatory levels, across the wider value chain. This includes quality control, monitoring, and inspection, but also packaging, product promotion, and retail, in order to raise the profile, reputation, and overall competitiveness of Russian products on the Chinese market. ${ }^{91}$

\section{Agri-Food Trade in ConteXt: Remaining OBstacles}

It is clear that the agricultural trade relationship between the two countries is deepening. At the same time, however, declarative statements from officials, such as the putative bilateral 'soybean industry alliance', belie the fact that cooperation is proceeding from an extremely low starting point. The removal of phytosanitary barriers for a range of products is very recent. This might invite some speculation that the opening of the Chinese market is motivated by geopolitical factors. However, negotiations and groundwork for such agreements take place over several years, the fruits of which are only now starting to be realised. Russian producers and distributors themselves point to growth being driven by their better understanding of the 'rules of the game', and their adaptation to Chinese 
demands over a longer period of time. ${ }^{92}$ Finally, any increased accommodation and policy facilitation for Russian exporters should be placed also in the context of China's opening towards a broader range of countries. In 2019 alone, China expanded access to its market to meat imports for an additional 16 countries. ${ }^{93}$ Moreover, it is ironically under conditions of strained U.S.-China relations that China has been locked increased vastly increased purchases of U.S. agricultural products under the Phase One trade deal. However, Russian exporters will not be substantially affected due to dissimilar trade profiles vis-à-vis the United States. ${ }^{94}$

Indeed, Russia-China agri-food trade over the last several years has more been marked by the removal of existing political and technical bottlenecks to the point of more normalised market-based relations. Thus, while wider geopolitical dynamics and any broader Russia-China entente are not irrelevant to the agri-food trade, other factors loom larger. These include, for the medium if not long term, obstacles including broader policy misalignment, market dynamics, as well as operational barriers of both hard and soft infrastructure.

At a basic level, Russian export strengths are not necessarily well aligned with Chinese demand due to China's grain self-sufficiency policies. The 'Export of AIC Products (2018-2024)' plan also explicitly notes the difficulty of gaining access to the Chinese market due to domestic protectionism. But similar policies on the Russian side also limit the prospects for increasing Chinese exports to Russia, where there has been increasing focus on substituting imports of fruits and vegetables. And despite other Russian statements to the contrary, Chinese demand for unprocessed soybeans is also potentially misaligned with Russian goals to increase the export of higher-value products, as Russian Minister of Agriculture Dmitrii Patrushev has noted. ${ }^{95}$

Non-tariff barriers also hinder trade. According to a joint report by authors from the Russian International Affairs Council and Chinese Academy of Social Sciences, these 'have the greatest negative impact on mutual trade in agricultural products'. ${ }^{96}$ Sanitary and phytosanitary measures for export to China are extremely strict. Though new protocols have been signed, in many cases Russian companies still need to obtain individual export licences. China follows the principle of regionalisation for some product categories. While this is better than wholesale bans, it also means that individual Russian regions need to be cleared for export. Other categories are on the whole not allowed into the Chinese market. Russian exporters must also comply with tough technical regulations 
regarding quality certification, specific packaging and labelling requirements, as well as complicated customs formalities. ${ }^{97}$ This goes both ways: in 2019 and 2020 alone, there were a number of restriction imposed on Chinese agricultural exports to Russia, including a ban on stone fruits from China in August 2019, and in January 2020 restrictions on citrus fruits as well as certain fish and seafood products. During early 2020, many Russian food retailers also suspended Chinese agricultural supplies due to concerns over COVID-19. ${ }^{98}$

On the market side, China is often idealised as having unlimited absorptive capacity, but it is also among the 'most demanding' markets in the world not only to penetrate but also navigate. ${ }^{99}$ Understanding if not meeting specialised Chinese tastes and consumer preferences requires investment in baseline market analytics. As Patrushev has admitted, 'the Chinese are a difficult people, it takes a very long time to convince them that our products are better. They are picky and, of course, selfinterested'. ${ }^{100}$ In terms of competitiveness in higher-value products, particularly in the oilseeds, livestock, and dairy sectors, Russia lags well behind established players. ${ }^{101}$ Russia must also compete with as well as emergent agricultural players and fellow CIS countries such as Ukraine, Kazakhstan, as well as a range of other countries that are seeking to increase agricultural exports to China in areas where Russia has advantage. Meanwhile, growing consumer emphasis is on the quality of food, to include food safety, healthiness, as well as organic production. ${ }^{102}$ Quality control including resolving issues with counterfeit products for eco-brands or dairy will be important. ${ }^{103}$ How much Chinese consumption will continue to grow in volume is another question. Most recently, Xi Jinping's August 2020 directives which place responsibility on individual citizens to cut (wasteful) food consumption, may also soon be reflected in the market. ${ }^{104}$

Another important obstacle is infrastructure. The bulk of Russian agricultural production is currently concentrated in the European part of the country. Transport either proceeds via freight, which is quicker but more expensive, through the body of the continent, or via marine shipping from the West passing Europe, Africa, and the Indian Ocean. From the western part of Russia, it can take up to 60 days for products to reach their destination in China's eastern seaports. ${ }^{105}$ The Ministry of Agriculture's export plan entails an additional R30 billion of development of 'transportoriented agricultural logistics' by 2024. For the time being, however, even RFE's proximity to China does not necessarily translate to cheaper 
or more efficient logistics. Lack of, or underdeveloped infrastructure, including grain terminals and port facilities, makes a range of investment, development, storage as well transport activities more expensive. ${ }^{106}$ Current vehicle-based transport modalities, slow customs procedures, and outdated facilities in the RFE add to the inefficiency. Lengthy customs procedures can hinder the transport of perishable products. ${ }^{107}$

Finally, RFE agricultural development in general continues to face deep challenges, with or without Chinese capital. ${ }^{108}$ There has been a longterm shortage of local labour in the region, and although the region has depended on Chinese immigrants for labour, their contribution was waning even before the COVID pandemic. ${ }^{109}$ During the COVID-19 pandemic, the Minister of Agriculture for Primorskii krai, Andrei Bronz, reported that due to the lack of Chinese and other foreign migrants usually engaged in vegetable cultivation, alternative labour was found through the use of students and convicts. ${ }^{110}$ This practice also affects soy cultivation. ${ }^{111}$ Finally, extreme weather events, including massive floods in the RFE in 2013 and again in 2019, which took tens of thousands of hectares of farmland out of commission and decreased crop yields, may increase as consequences of climate change worsen. ${ }^{112}$

\section{OuTLOOK}

While there are elements of market complementarity between the two markets, overall trade is strongly shaped by domestic political priorities on both sides, which are not always aligned. The evolution from adversaries to strategic partners in recent years means that politics continue to influence trade in general and agricultural trade, both directly and indirectly. Moreover, self-sufficiency policies are unlikely to change on either side. Russian officials are less interested in the level of bilateral trade than they are in increasing exports. And it means that there is limited scope for expanding grain (soy) exports to China. So far, Russia does not yet feature as a significant player in Chinese agri-food markets outside of fish, seafood, and chocolate confectionaries.

Nevertheless, with the recent opening of the Chinese market to a range of Russian products, prospects are certain that agri-food trade value will grow in long if not medium term, and in the export-oriented direction in which Russian policymakers are seeking. Whether the current trajectory is sufficient to help meet the 2024 export target of the Russian government remains to be seen. On the Chinese side, its demand for Russian soy 
will surely be influenced by trade relations with the United States and the fulfillment of the Phase One Trade Deal. On the Russian side, funding for overcoming the range of obstacles to enhance agri-food trade listed in this chapter, including infrastructure, will be necessary. Finally, beyond accessing the Chinese market, the broader competitiveness of Russian agri-food products on the Chinese market will also require substantial work by Russian industry players themselves.

\section{Notes}

1. Kremlin, 'Russia Calling! Investment Forum', 28 November. http:// en.kremlin.ru/events/president/news/59216\#sel=57:1:D33,57:32:pnj. Accessed 10 September 2020.

2. Thomas Grove and Anatoly Kurmanaev, 'A Surprise Winner from the U.S.-China Trade Spat: Russian Soybean Farmers', Wall Street Journal, 21 February 2019. https://www.wsj.com/articles/russia-exploits-u-schina-trade-tensions-to-sell-more-soybeans-11550745001. Accessed 29 September 2020.

3. Paul Bolt and Sharyl Cross, China, Russia, and Twenty-First Century Global Geopolitics (Oxford: Oxford University Press, 2018).

4. TASS, 'Russia, China Not Seeking Military Alliance-Lavrov', 2 November 2019. https://tass.com/politics/1086654. Accessed 29 September 2020.

5. Bobo Lo, Axis of Convenience: Moscow: Beijing, and the New Geopolitics (London: Chatham House, 2008); Alexander Gabuev, 'China and Russia: Friends with Strategic Benefits', The Lowy Interpreter, 7 April 2017. https://www.lowyinstitute.org/the-interpreter/china-and-russiafriends-strategic-benefits. Accessed 11 October 2020.

6. Charles Clover, 'Russia Resumes Advanced Weapons Sales to China', Financial Times, 3 November 2016.

7. Artyom Lukin, 'The Russia-China Entente and Its Future', International Politics (2020). https://doi.org/10.1057/s41311-020-00251-7.

8. Jonathan E. Hillman, 'China and Russia: Economic Unequals', Center for Strategic and International Studies, July 2020. https://www.csis. org/analysis/china-and-russia-economic-unequals. Accessed 11 October 2020; Ivan Zuenko, 'A Milestone, Not a Turning Point: How China Will Develop the Russian Far East', Carnegie Moscow Center, 8 November 2018. https://carnegie.ru/commentary/77671. Accessed 11 October 2020.

9. People's Daily, 'Zhongguo you naxie houban guanxi', 31 March 2014. http://world.people.com.cn/n/2014/0331/c1002-24778739. html. Accessed 31 July 2020. 
10. Kremlin, 'Press Statements Following Russian-Chinese Talks', 5 June 2019. http://en.kremlin.ru/events/president/news/60672. Accessed 31 July 2020; and Sina, 'Pujing zongtong shi wo zui hao de zhixin pengyou', 5 June 2019. https://finance.sina.com.cn/china/gncj/201906-05/doc-ihvhiews6855269.shtml. Accessed 3 August 2020.

11. Zuenko, 'A Milestone'.

12. Neil MacFarquhar, 'As Chinese Flock to Siberia's Lake Baikal, Local Russians Growl', New York Times, 2 May 2019. https://www.nytimes. $\mathrm{com} / 2019 / 05 / 02 /$ world/europe/chinese-lake-baikal-tourism-russia. html? searchResultPosition=l. Accessed 4 November 2020.

13. PRC Ministry of Commerce, 'Yi jidu zhong e maoyi e zengzhang $3.4 \%$ ', 26 April 2020. http://ru.mofcom.gov.cn/article/jmxw/202004/202 00402959212.shtml. Accessed 30 July 2020.

14. Alexander Lukin, 'Russia's Pivot to Asia: Myth or Reality?', Strategic Analysis 40, no. 6 (2016): 573-89; and Alexander Gabuev, 'A Pivot to Nowhere: The Realities of Russia's Asia Policy', Carnegie Moscow Center, 22 April 2016. https://carnegie.ru/commentary/ 63408. Accessed 11 October 2020.

15. Elena Kuzmina, 'Free Trade Zones Within the EAEU', 31 October 2019. https://russiancouncil.ru/en/analytics-and-comments/analytics/ free-trade-zones-with-the-eaeu/. Accessed October 11, 2020.

16. Tong Guangji and Shi Lei, 'Zhong e nongchanpin maoyi ji qi bijiao youshi, hubu xing yanbian qushi', Journal of South China Agricultural University 15, no. 5 (2016): 110-22.

17. Yu Min, Jiang Minglun and Geng Jianzhong, 'Zhong e nongye hezuo xin jiyu ji duice yanjiu', World Agriculture, no. 8 (2015): 4-9. (Original title of journal in Chinese.)

18. People's Daily, 'Zhong e nongye hezuo 'xin shidai' laile ma?', 16 August 2020. http://world.people.com.cn/nl/2019/0816/c1002-31300848. html. Accessed 29 September 2020.

19. A. Y. Osinina, Sun Polin and Jiang Jing, 'Rossiisko-Kitaiskoe sotrudnichestvo $\mathrm{v}$ oblasti sel'skogo khoziaistva: sostoianie i perspektivy', May 2019. https://russiancouncil.ru/papers/Russia-China-AgriculturePolicybrief21-Ru.pdf. Accessed 5 November 2020.

20. Elena Sukhorukova, 'Kitai stal krupneishim pokupatelem Rossiiskogo miasa', 28 July 2020. https://www.rbc.ru/business/28/07/2020/5fl ea7a19a79472749e49b3c. Accessed 29 September 2020.

21. Yu Min, et al., 'Zhong e nongye'.

22. Osinina et al., 'Rossiisko-Kitaiskoe sotrudnichestvo'.

23. Stephen K. Wegren, Alexander Nikulin and Irina Trotsuk, Food Policy and Food Security: Putting Food on the Russian Table (Lanham, MD and London, UK: Lexington Books, 2018); and Russian Government, 'First Meeting of the Government Commission on Import Substitution', 
11 August 2015. http://government.ru/en/news/19246/. Accessed 8 September 2020.

24. Russian Ministry of Agriculture, 'Za poslednie 5 let Rossiia sokratila import prodovol'stviia na tret', 5 August 2019. https://mcx.gov.ru/ press-service/news/za-poslednie-5-let-rossiya-sokratila-import-prodov olstviya-na-tret/. Accessed 18 September 2020.

25. Kremlin, 'Address to the Federal Assembly', 12 December 2012. http:// en.kremlin.ru/events/president/news/17118. Accessed 29 September 2020 .

26. PRC State Council, 'Zhongguo de liangshi wenti,' 1996. http:// www.scio.gov.cn/zfbps/ndhf/1996/Document/307978/307978.htm. Accessed 3 February 2016; and PRC State Council, 'Food Security in China,' 2019. http://www.scio.gov.cn/zfbps/32832/Document/166 6228/1666228.htm. Accessed 29 September 2020.

27. See Stephen K. Wegren, 'Can Russia's Food Exports Reach $\$ 45$ Billion in 2024?', Post-Communist Economies 32, no. 2 (2020): 147-75.

28. Russian Export Center, 'Natsional'nyy proyekt "Mezhdunarodnaia kooperatsiia i eksport"', n.d., https://www.exportcenter.ru/company/intern ational-cooperation/priority/. Accessed 28 September 2020.

29. Natalia Karlova and Eugenia Serova, 'Prospects of the Chinese Market for Russian Agri-Food Exports', Russian Journal of Economics 6, no. 1 (2020): 71-90; and Russian Ministry of Agriculture, 'Agroeksport 2030: trendy i perspektivy', 2020. https://mcx.gov.ru/upload/iblock/ 186/186a255a5aefae001e3d6fle7a93089d.pdf. Accessed 20 September 2020.

30. Stephen K. Wegren, Alexander M. Nikulin and Irina Trotsuk, 'Russia's Tilt to Asia and Implications for Agriculture', Eurasian Geography and Economics 56, no. 2 (2015): 127-49.

31. Kremlin, 'Plenarnoe zasedanie Vostochnogo ekonomicheskogo foruma', 12 September 2018. http://kremlin.ru/events/president/news/58537. Accessed 29 September 2020.

32. Ibid.

33. Kremlin, 'Zasedanie prezidiuma Gossoveta', 4 September 2019. http:// kremlin.ru/events/president/news/61443. Accessed 29 September 2020 .

34. Anna Bondarenko, 'Za schet ryby i soi', 28 March 2019. https:// rg.ru/2019/03/28/reg-dfo/k-2024-godu-eksport-selhozprodukcii-izdfo-vyrastet-v-16-raza.html. Accessed 4 September 2020.

35. Kremlin, 'Zasedanie prezidiuma Gossoveta'.

36. Kremlin, 'Plenarnoe zasedanie'.

37. Far East Development Fund, 'Russia-China Agricultural Fund Is Going to Invest up to 10 bln USD', n.d. https://www.fondvostok.ru/ en/press/press_release/russia-china-agricultural-fund-is-going-to-inv 
est-up-to-10-bln-usd-into-agricultural-projects-under-/. Accessed 28 September 2020.

38. Kremlin, 'Plenarnoe zasedanie'.

39. Zuenko, 'A Milestone'.

40. Xu Zhenbao and Li Zhemin, 'Yidai yilu zhanlue xia zhongguo yu eluosi nonye hezuo tanxi', 192-6.

41. PRC Ministry of Commerce, 'Zhong e zai eluosi yuandong diqu hezuo fazhan guihua (2018-2024 nian)', 2018. http://images.mofcom. gov.cn/www/201811/20181115164728217.pdf. Accessed 11 October 2020.

42. Jiayi Zhou, 'Chinese Agrarian Capitalism in the Russian Far East', Third World Thematics: A TWQ Journal 1, no. 5 (2016): 612-32.

43. Andrey Zakharov and Anastasiya Napalkova, 'Uyedut kitaitsy-vse zarastet: kak fermery iz KNR osvaivaiut Rossiiskii Dal'nii Vostok', 21 October 2019. https://www.bbc.com/russian/features-49978027. Accessed 20 September 2020.

44. Osinina et al., 'Rossiisko-Kitaiskoe sotrudnichestvo'.

45. Yu et al., 'Zhong e nongye'.

46. China-Russia Information Network, 'E zhongli; bixu jiangdi yuandong diqu dui jinkou shuchai yilai', l September 2020. http:// www.chinaru.info/zhongejmyw/zhongemaoyi/61712.shtml. Accessed l October 2020.

47. Inna Ganenko, 'Terra inkognita dlia Rossiiskogo agroeksporta. Kakovy perspektivy vyvoza prodovol'stviia v Kitai', 7 May 2019. https:// www.agroinvestor.ru/markets/article/31685-terra-inkognita/. Accessed 29 September 2020.

48. Karlova and Serova, 'Prospects of the Chinese Market'.

49. RIA Novosti, 'Dmitrii Patrushev: sel'skoe khoziaistvo-uzhe ne chernaia dyra i ne ssylka', 21 December 2018. https://ria.ru/20181221/154838 1117.html. Accessed 29 September 2020.

50. Sina, 'Zhong e ni qianshu youguan eluosi xiang zhongguo chukou liangshi yidingshu', 17 October 2020. http://finance.sina.com.cn/ world/20151017/160123502990.shtml. Accessed 4 August 2020.

51. PRC Ministry of Commerce, 'Zhonghua remin gongheguo haiguan zong shu gonggao 2019 nian di 141 hao', 23 September 2019. http:// www.mofcom.gov.cn/article/b/g/201909/20190902901102.shtml. Accessed 31 July 2020.

52. Ganenko, 'Terra inkognita'.

53. Osinina et al., 'Rossisko-Kitaiskoe sotrudnichestvo'.

54. Ibid.

55. Ganenko, 'Terra inkognita'.

56. Fred Gale, James Hansen and Michael Jewison, 'China's Growing Demand for Agricultural Imports', Economic Research Service, 
Economic Information Bulletin 136, February 2015, p. 7. https://www. ers.usda.gov/webdocs/publications/43939/eib-136.pdf?v=0. Accessed 12 October 2020.

57. Sukhorukova, 'Kitai stal krupneishim'.

58. Russian Ministry of Agriculture, 'V 2019 godu eksport miasa ptitsy v Kitai mozhet prevysit' $100 \mathrm{mln}$ dollarov', 9 September 2019. https:// mcx.gov.ru/press-service/news/v-2019-godu-eksport-myasa-ptitsy-vkitay-mozhet-prevysit-100-mln-dollarov/. Accessed 29 September 2020.

59. Ekaterina Diatlovskaia, 'Miratorg pervym otpravil miaso ptitsy v Kitai', 4 March 2019. https://www.agroinvestor.ru/regions/news/31333miratorg-pervym-otpravil-myaso-ptitsy-v-kitay/. Accessed 29 September 2020.

60. Ekaterina Diatlovskaia, 'Minsel'khoz: v 2019 godu Rossiia postavit v KNR miasa ptitsy na $\$ 100 \mathrm{mln}$ ', 9 September 2019. https://www.agr oinvestor.ru/markets/news/32385-rossiya-postavit-v-knr-myasa-ptitsyna-100-mln/. Accessed 29 September 2020.

61. China-Russia Information Network, 'Xuqiu juda eluosi ji zhua yao kou kai zhongguo shichang damen', 24 June 2019. http://chinaru.info/ zhongejmyw/zhongemaoyi/57563.shtml. Accessed 29 September 2020; and Sukhorukova, 'Kitay stal krupneyshim'.

62. United States Department of Agriculture, Foreign Agricultural Service, 'China-Poultry and Products Annual', GAIN Report CH19048, 31 July 2019. https://apps.fas.usda.gov/newgainapi/api/report/ downloadreportbyfilename?filename $=$ Poultry $\% 20$ and $\% 20$ Products $\% 20 \mathrm{~A}$ nnual_Beijing_China\%20-\%20Peoples\%20Republic\%20of_7-29-2019. pdf. Accessed November 5, 2020.

63. China Daily, 'China's Meat Import Rises Fast in 2019', 14 January 2020. https://www.chinadaily.com.cn/a/202001/14/WS5eld3308a3 10128217270c72.html. Accessed 29 September 2020.

64. Reuters Staff, 'China Opens Its Market to Russian Beef Producers', 17 January 2020. https://www.reuters.com/article/russia-china-beef/ update-1-china-opens-its-market-to-russian-beef-producers-idUSL8N29 M3T1. Accessed 2 August 2020.

65. Keith Bradsher and Ailin Tang, 'China Responds Slowly, and a Pig Disease Becomes a Lethal Epidemic', New York Times, 17 December 2019. https://www.nytimes.com/2019/12/17/business/china-pigs-afr ican-swine-fever.html? searchResultPosition=1. Accessed 4 November 2020.

66. China Daily, 'China's Meat Import Rises Fast in 2019'.

67. Dominique Patton, 'China's Pork Demand Hits a Peak, Shocking Producers, as Diets Get Healthier', 20 June 2017. https://www.reuters. com/article/us-china-meat-demand-insight/chinas-pork-demand-hits- 
a-peak-shocking-producers-as-diets-get-healthier-idUSKBN19A31C. Accessed 4 August 2020.

68. Karlova and Serova, 'Prospects of the Chinese Market'.

69. PRC Ministry of Agriculture, 'Zhongguo nongye'.

70. Brad Gehrke and Lesley Ahmed, 'Agricultural Trade with China: Dairy Import Giant', U.S. International Trade Commission, 2019. https:// www.usitc.gov/publications/332/executive_briefings/ebot_brad_geh rke_lesley_ahmed_china_dairy_pdf.pdf. Accessed 29 September 2020.

71. Ganenko, 'Terra inkognita'.

72. Ibid.

73. Wang Ke, 'Guojian duoyuan hua jinkou dadou gongying tixi', 11 August 2018. http://xz.people.com.cn/n2/2018/0811/cl38901-31921770. html. Accessed 29 September 2020; Liu Hui, 'Woguo dadou jinkou duoyuan hua geju yijing xingcheng', 10 August 2018. http://www.chi nanews.com/gn/2018/08-10/8595520.shtml. Accessed 29 September 2020.

74. Xiao Zhongren and Zhao Yebing, 'Zhongguo qiye zizhu kuoda duoyuan hua jinkou qudao youxiao fensan meiguo dadou jinkou jianshao de fengxian', 14 August 2018. https://www.sohu.com/a/247099209_ 115239. Accessed 29 September 2020.

75. PRC Ministry of Commerce, 'Zhong e liang guochan yejie gong tan takuan dadou hezuo jujing', 22 November 2019. http://www.mof com.gov.cn/article/difang/201911/20191102915727.shtml. Accessed 2 August 2020.

76. Kvedomosti.ru, 'Kitai i Rossiia podpishut document o merakh po uvelicheniiu tovarooborota do \$200 mlrd', 10 September 2019. https://kvedomosti.ru/news/kitaj-i-rossiya-podpishut-dokument-omerax-po-uvelicheniyu-tovarooborota-do-200-mlrd.html. Accessed 10 September 2019.

77. Ibid.

78. Alena Uzbekova, 'Boby nastupaiut', 24 November 2019. https://rg. $\mathrm{ru} / 2019 / 11 / 24 / \mathrm{reg}$-dfo/soia-vyshla-na-vtoroe-mesto-v-eksporte-pro dukcii-apk-s-dalnego-vostoka.html. Accessed 20 September 2020.

79. Ivan Zuenko, 'Can Russia's Far East Feed China with Soy?', Carnegie Moscow Center, 9 October 2018. https://carnegie.ru/commentary/ 77443. Accessed 31 July 2020.

80. IKAR, 'Glava IKAR rasskazal, kak Rossiia mozhet uvelichit' proizvodstvo soi', 24 December 2018. http://ikar.ru/old/press/4679.html. Accessed 29 September 2020.

81. An Yushu, 'Shenru fenxi dangqian zhong e dadou zhongzhi maoyi hezuo: fazhan chengxiao cunzai wenti ji duice jianyi', 3 March 2020. http://www.chinaru.info/zhongejmyw/jingmaotegao/ 59787.shtml. Accessed 3 August 2020. 
82. Zuenko, 'Can Russia's Far East Feed China'.

83. China-Russia Information Network, 'Xuqiu juda eluosi ji zhua yao kou kai zhongguo shichang damen', 24 June 2019. http://chinaru.info/zho ngejmyw/zhongemaoyi/57563.shtml. Accessed 29 September 2020.

84. Ganenko, 'Terra inkognita'.

85. PRC Ministry of Commerce, 'Zhonghua remin gongheguo'.

86. Russian Government, 'Ustanovlen zapret na vyrashchivanie i razvedenie genno-inzhenerno-modifitsirovannykh organizmov na territorii Rossii', 29 July 2016. http://council.gov.ru/events/news/69701/. Accessed 3 August 2020.

87. COFCO, 'Zhongguo e nongye hezuo luodi shu qian dun eluosi dadou di su', 2 August 2019. http://www.cofco.com/cn/News/Allnews/ Press/2019/0802/47920.html. Accessed 2 August 2020.

88. Karlova and Serova, 'Prospects of the Chinese Market'.

89. Russian Ministry of Agriculture, 'Shokolad i Shokoladhye konditerskie isdeliia na rynke KNR', n.d. https://mcx.gov.ru/upload/iblock/4d6/ 4d6373a83dd841dcfl6891d99b077c01.pdf. Accessed 29 September 2020.

90. Karlova and Serova, 'Prospects of the Chinese Market'.

91. Russian Government, 'Brifing Aleksandra Tkachova po zavershenii zasedaniia', 25 April 2018. http://government.ru/dep_news/32455/. Accessed 29 September 2020.

92. Konstantin Shtepin, 'Nakormit' Kitai po-moskovski', 4 November 2019. https://rg.ru/2019/11/04/rossijskie-selhozproizvoditeli-vyhodiat-narynok-podnebesnoj.html. Accessed 29 September 2020.

93. PRC State Council, 'Jinkou rou, woguo 2019 nian you duole 16 ge laiyuan guo', 2019. http://www.scio.gov.cn/m/xwfbh/xwbfbh/ wqfbh/42311/42414/xgbd42421/Document/1671755/1671755. htm. Accessed 29 September 2020.

94. Vasily Erokhin, 'Peremirie' v torgovom protivostoianii SShA i Kitaia: vozmozhne posledstviia dlia restrukturizatsii mirovoi torgovli prodovol'stviem', Marketing $i$ Logistika, 27, no. 1 (2020): 12-35.

95. RIA Novosti, 'Dmitrii Patrushev: sel'skoe khoziaistvo'.

96. Osinina et al., 'Rossiisko-Kitaiskoe sotrudnichestvo'.

97. Ibid.

98. Ekaterina Burlakova and Tatiana Romanova, 'Magaziny i restorany ishchut zamenu Kitaiskim produktam', 3 February 2020. https://www. vedomosti.ru/business/articles/2020/02/03/822131-zamenu-kitais kim-produktam. Accessed 3 August 2020.

99. Karlova and Serova, 'Prospects of the Chinese Market'.

100. RIA Novosti, 'Dmitrii Patrushev: sel'skoe khoziaistvo'.

101. Karlova and Serova, 'Prospects of the Chinese Market'; and Sukhorukova, 'Rossiiskoe miaso'. 
102. Nielsen Insights, 'New Eating Trends in China: The Healthier the Better', 22 September 2016. https://www.nielsen.com/cn/en/pressreleases $/ 2016 / \mathrm{New}$-Eating-Trends-in-China-the-Healthier-the-Better/. Accessed 4 August 2020.

103. Osinina et al., 'Rossiisko-Kitaiskoe sotrudnichestvo'.

104. PRC Government, 'Xi Jinping dui zhizhi canyin langfei xingwei zuochu chong yao zhishi', 11 August 2020. http://www.gov.cn/xinwen/202008/11/content_5534026.htm. Accessed 30 September 2020.

105. 'Elousi niurou lai liao: bu ju shichang jingzheng 2020 nian jihua chukou 1 wan dun', 12 May 2020. https://finance.sina.cn/2020-05-12/detailiirczymk1217263.d.html?cre $=$ tianyi\& $\bmod =$ wpage $\& l o c=6 \& \mathrm{r}=32 \& \mathrm{rfunc}=$ $16 \& \mathrm{tj}=$ none\&tr $=32$. Accessed 2 August 2020.

106. An, 'Shenru fenxi'.

107. Osinina et al., 'Rossiisko-Kitaiskoe sotrudnichestvo'.

108. Bondarenko, 'Za schet ryby i soi'.

109. Ivan Zuenko, 'Pandemic Changes Face of Farming in Russian Far East', 18 December 2020. https://carnegie.ru/commentary/83484?utm_sou rce=rssemail\&utm_medium $=$ email\&mkt_tok=eyJpIjoiTUdNMk9UZG hZVGt5TXpCaSIsInQiOiJhTIF5MVZ0OWFCQkxIN0tBOFNpRnhlW nptUlpxOUhcL3JudXJBS2hLRTNcL2tVVXRaYWJHZjJmRjdGcEht MnY3MmlWOFVqclFINCtKTDdTYW5LSVhcL3hLYUtwTml5dEtI UDBWaUNsb3pxekN3YjJKMzlGanhUTnlHUGFLa0ZROGtObiJ9. Accessed 24 December 2020.

110. Interfax, 'V Primor'ye privlekut $\mathrm{k}$ posevnoi uchashchikhsia i zaklyuchennykh iz-za nekhvatki migrantov', 28 April 2020. https://www.interfax. ru/russia/706365. Accessed 29 September 2020.

111. Polina Nikolskaya, 'Labour Shortage Crippling Chinese Investments in Russian Soy', 17 August 2020. https://www.nasdaq.com/articles/lab our-shortage-crippling-chinese-investments-in-russian-soy-2020-08-17. Accessed 11 October 2020.

112. Kremlin, 'Zasedanie prezidiuma'.

\section{SELECTEd Bibliography}

Bolt, Paul and Sharyl Cross. China, Russia, and Twenty-First Century Global Geopolitics. Oxford: Oxford University Press, 2018.

Bradsher, Keith and Ailin Tang. 'China Responds Slowly, and a Pig Disease Becomes a Lethal Epidemic'. New York Times, 17 December 2019. https://www.nytimes.com/2019/12/17/business/china-pigs-africanswine-fever.html?searchResultPosition=1. Accessed 4 November 2020.

Clover, Charles. 'Russia Resumes Advanced Weapons Sales to China'. Financial Times, 3 November 2016. 
Food and Agriculture Organization. Food Outlook: Biannual Report on Global Food Markets. Rome: FAO, 2019.

Gabuev, Alexander. 'A Pivot to Nowhere: The Realities of Russia's Asia Policy'. Carnegie Moscow Center, 22 April 2016. https://carnegie.ru/commentary/ 63408.

Gabuev, Alexander. 'China and Russia: Friends with Strategic Benefits'. The Lowy Interpreter, 7 April 2017. https://www.lowyinstitute.org/the-interp reter/china-and-russia-friends-strategic-benefits.

Hillman, Jonathan E. 'China and Russia: Economic Unequals'. Center for Strategic and International Studies, July 2020. https://www.csis.org/ana lysis/china-and-russia-economic-unequals.

Karlova, Natalia and Eugenia Serova. 'Prospects of the Chinese Market for Russian Agri-Food Exports'. Russian Journal of Economics 6 (2020): 71-90.

Lo, Bobo. Axis of Convenience: Moscow: Beijing, and the New Geopolitics. London: Chatham House, 2008.

Lukin, Alexander. 'Russia's Pivot to Asia: Myth or Reality?'. Strategic Analysis 40 , no. 6 (2016): 573-89

Lukin, Artyom. 'The Russia-China Entente and Its Future'. International Politics (2020). https://doi.org/10.1057/s41311-020-00251-7.

MacFarquhar, Neil. 'As Chinese Flock to Siberia's Lake Baikal, Local Russians Growl'. New York Times, 2 May 2019. https://www.nytimes.com/2019/ 05/02/world/europe/chinese-lake-baikal-tourism-russia.html?searchResult Position $=1$.

Nikolskaya, Polina. 'Labour Shortage Crippling Chinese Investments in Russian Soy'. 17 August 2020. https://www.nasdaq.com/articles/labour-shortage-cri ppling-chinese-investments-in-russian-soy-2020-08-17.

Wegren, Stephen K. 'Can Russia's Food Exports Reach \$45 Billion in 2024?' Post-Communist Economies 32, no. 2 (2020): 147-75.

Wegren, Stephen K., Alexander Nikulin and Irina Trotsuk. Food Policy and Food Security: Putting Food on the Russian Table. Lanham, MD and London, UK: Lexington Books, 2018.

Wegren, Stephen K., Alexander M. Nikulin and Irina Trotsuk. 'Russia's Tilt to Asia and Implications for Agriculture'. Eurasian Geography and Economics 56, no. 2 (2015): 127-49.

Zhou, Jiayi. 'Chinese Agrarian Capitalism in the Russian Far East'. Third World Thematics: A TWQ Journal 1, no. 5 (2016): 612-32.

Zuenko, Ivan. 'A Milestone, Not a Turning Point: How China Will Develop the Russian Far East'. Carnegie Moscow Center, 8 November 2018. https://car negie.ru/commentary/77671. 
Open Access This chapter is licensed under the terms of the Creative Commons Attribution 4.0 International License (http://creativecommons.org/licenses/ by $/ 4.0 /$ ), which permits use, sharing, adaptation, distribution and reproduction in any medium or format, as long as you give appropriate credit to the original author(s) and the source, provide a link to the Creative Commons license and indicate if changes were made.

The images or other third party material in this chapter are included in the chapter's Creative Commons license, unless indicated otherwise in a credit line to the material. If material is not included in the chapter's Creative Commons license and your intended use is not permitted by statutory regulation or exceeds the permitted use, you will need to obtain permission directly from the copyright holder.

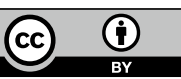

